\title{
Çocuk Yoğun Bakım Ünitesine Olan Talebin Zaman Serisi Yöntemleri ile Tahmin Edilmesi
}

\author{
Esra Karakaş ${ }^{1 *}$ \\ ${ }^{1}$ Adana Alparslan Türkeş Bilim ve Teknoloji Üniversitesi, İşletme Fakültesi, İşletme Bölümü, Adana, Türkiye (ORCID: 0000-0002-8333-3091)
}

(İlk Geliş Tarihi 25 Eylül 2019 ve Kabul Tarihi 27 Ekim 2019)

(DOI: $10.31590 /$ ejosat.624407)

\begin{abstract}
ATIF/REFERENCE: Karakaş, E. (2019). Çocuk Yoğun Bakım Ünitesine Olan Talebin Zaman Serisi Yöntemleri ile Tahmin
\end{abstract} Edilmesi. Avrupa Bilim ve Teknoloji Dergisi, (17), 454-462.

\begin{abstract}
$\ddot{\mathbf{O} z}$
Çocuk yoğun bakım üniteleri (ÇYBÜ), kesintisiz hizmet sunan, birden fazla organ ve sistem yetersizliğinden kaynaklanan ya da geçirdikleri cerrahi operasyonlar sonrası genel durumları ve bulgularının yakın takip edilmesi gereken 1 ay-18 yaş arası çocukların bakım ve tedavilerinin yapıldığı ünitelerdir. Gelişmiş ülkelerde pediatrik yoğun bakım hizmetlerinin çocuk sağlığına önemli katkıda bulunduğu; etkin pediatrik yoğun bakım hizmeti olmaması durumunda çocuk ölümlerinin artacağı bilinmektedir. Bu nedenle çocuk yoğun bakım ünitelerinde ihtiyaç duyulan miktarda kaynak bulundurulması oldukça önem arz eder. Kaynak planlamasının en iyi şekilde gerçekleştirilmesi ise uygun bir yöntemle elde edilmiş talep tahmini verilerine bağlıdır. Mevcut çalışmada, Adana ilinde yer alan bir hastanenin çocuk yoğun bakım ünitesine 2015- 2018 yılları arasında gelen aylık hasta sayısı verileri dikkate alınarak zaman serisi analizi yapılmış ve uygun talep tahmin yöntemi belirlenmeye çalışılmıştır. Otoregresif birleştirilmiş hareketli ortalamalar (ARIMA), hareketli ortama ve üstel düzeltme yöntemleri kullanılarak tahminler elde edilmiş ve bu yöntemlere ait performans ölçütleri hesaplanmıştır. Performans analizleri, Ortalama Mutlak Yüzde Hata (OMYH), Ortalama Mutlak Hata (OMH) ve Hata Karesi Ortalaması (HKO) gibi hata ölçütleri dikkate alınarak yapılmıştır. Bütün yöntemler, kabul edilebilir seviyede hata ölçütleri ortaya koymasına rağmen, mevcut ölçütler ile kıyaslamalar yapılması neticesinde üç aylık hareketli ortalama yönteminin en uygun yöntem olduğu ortaya çıkmıştır. Önerilen tahmin yöntemi ile elde edilen tahmin değerlerinin, ilgili hastanenin çocuk yoğun bakım ünitesi kaynak planlaması için önemli bir girdi oluşturacağı düşünülmektedir.
\end{abstract}

\section{Estimating Demand for Pediatric Intensive Care Unit by Time Series Methods}

\begin{abstract}
Pediatric Intensive Care Units (PICUs) are units that provide uninterrupted service, care and treatment of children between 1 month and 18 years of age due to multiple organ and system deficiencies or whose general conditions and findings should be followed closely after surgical operations. It is known that pediatric intensive care services in developed countries contribute significantly to child health and child mortality will increase if there is no effective pediatric intensive care service. For this reason, it is very important to have the necessary resources in pediatric intensive care units. Optimizing resource planning requires demand forecast data that has been obtained through an appropriate method. In the present study, time series analysis was conducted by considering the monthly number of patients coming to the pediatric intensive care unit of a hospital in Adana between 2015 and 2018 and an appropriate forecasting method was determined. Autoregressive integrated moving average (ARIMA), moving averages and exponential smoothing methods were used.
\end{abstract}

* Esra KARAKAŞ: Adana Alparslan Türkeş Bili ve Teknoloji Üniversitesi, İşletme Fakültesi, İşletme Bölümü, Adana, Türkiye, ORCID: 0000-00028333-3091, ekarakas@atu.edu.tr 
Prediction performance were conducted by taking into account Mean Absolute Percentage Error (MAPE), Mean Absolute Error (MAE) and Mean Square Error (MSE). Although all the methods are acceptable, the three-month moving average method was the most suitable method. It is considered that the forecasts obtained by the proposed method would provide an important input for the resource planning of the pediatric intensive care unit of the relevant hospital.

Keywords: Pediatric Intensive Care Units, Demand Forecast, ARIMA, Moving Averages, Exponantial Smoothing

\section{Giriş}

Talep tahmini, üretim veya hizmet sektörlerinde çıktının (belirli olan bir ürünün ya da hizmetin), gelecek dönemlerde ne miktarda olacağını belirlemek için geçmiş dönem verilerinin düzenlenmesi ve analiz edilmesi sürecidir (Kress\&Snyder,1994:175). Bu karar sürecinde kullanılan tahmin teknikleri iki gruba ayırılabilir. Bunlar sayılabilen (kantitatif) ve sayılamayan (kalitatif) tekniklerdir. Sayılabilen tekniklere örnek olarak; zaman serisi analizleri, nedensel ekonometri modelleri, regresyon modelleri ve karma istatistik modelleri verilebilir. Sayılamayan teknikler arasında; tecrübe ve sezgiye dayalı tahminler, geçmişi canlandırma, senaryo yazma, beyin firtınası bulunmaktadır (Güner, 2014:51). Karar vericiler öncelikle tahmin yapacakları sorunun yapısına en uygun tahminleme tekniğini belirlemelidir (Özdemir, 2006:105).

Sağlık hizmetlerinde talep tahmini farklı ihtiyaçlar için yapılabilir. Tıbbi malzemelerin stok maliyetlerinin kontrolünün sağlanması veya tıbbi malzemeye olan ihtiyacın karşılanabilmesini sağlayacak tedariğin yapılabilmesi için talep tahmininin gerçekleştirilmesi örnek olarak verilebilir. Bu kapsamda Özüdoğru ve Görener (2015), İstanbul'da bir hastanede kullanılan temel medikal malzemelerin 20102014 yıllarındaki talep verileri ile bir talep tahmini uygulaması yapmışlardır. Yiğit (2016), Süleyman Demirel Üniversitesi Hastanesinin serum seti tüketimini kantitatif tahmin yöntemleri ile analiz etmiş ve en uygun tahmin modelini belirleyerek, gelecek dönemlere ait serum seti tüketiminin tahmini yapmıştır. Bu çalışmaların yanısıra, hastanede farklı birimlere gelecek hastaların tahmin edilerek, gerekli olan yatak, doktor, personel ve diğer donanım ihtiyacının belirlenmesi de hastane yönetimi açından oldukça önemli bir ihtiyaçtır. Sarıyer (2018), acil servislerde operasyonların daha doğru planlanması, aşırı yoğunluk ile baş etmek için stratejiler geliştirilmesi ve hasta memnuniyetinin artması açısından; talebin en az hata ile tahmin edilmesinin önem arz ettiğini vurgulamıştır. Bu bağlamda, İzmir'de büyük ölçekli bir üçüncü basamak eğitim hastanesinin acil servis talebini zaman serileri analizi kullanılarak tahmin etmiştir.

Yoğun bakım üniteleri, hastanerin oldukça önemli birimlerinden biridir. Çocuk yoğun bakım üniteleri (ÇYBÜ), hayatı tehdit altında olan süt çocuğu, çocuk ve ergenlerin yaşamsal bulgularının izlendiği ve desteklendiği, çoğunlukla multidisipliner tedavi yaklaşımlarının uygulandığı, diğer pediatri kliniklerine göre daha fazla sayıda personel ve donanıma ihtiyaç duyulan özel birimlerdir (Konca, Tekin, Karakoç, Turgut, 2015). Gelişmiş ülkelerde pediatrik yoğun bakım hizmetlerinin çocuk sağlığına önemli katkıda bulunduğu; etkin pediatrik yoğun bakım hizmeti olmasaydı çocuk ölümlerinin iki katına çıkabileceği tahmin edilmektedir. Dolayısıyla çocuk yoğun bakımın, çocuk ölümlülüğünü düşük tutmakta önemli rol oynadığı düşünülmektedir (Çocuk acil tıp ve yoğun bakım derneği, ty.). Bu derece kritik bir sağlı ünitesi için kapasite planlaması yapılırken uygun bir tahmin metodundan elde edilen talep tahminlerinin girdi olarak dikkate alınması, planlamanın daha iyi bir şekilde gerçekleştirilebilmesi açısından oldukça önemlidir.

Bu çalışmadaki amaç, Adana'da büyük ölçekli bir eğitim hastanesinde ÇYBÜ’ne olan talebin uygun zaman serisi metodu kullanılarak tahmin edilmesidir. Çalışmada, hastanenin Ocak 2015 ile Aralık 2018 tarihleri arasından ÇYBÜ’nde tedavi görmüş aylık hasta sayıları verileri dikkate alınmıştır. Zaman serisi yöntemlerinden, hareketli ortalama, üstel düzeltme ve ARIMA modeli yöntemleri test edilmiştir.

\section{Materyal ve Metod}

\subsection{Materyal}

Mevcut çalışmada, Adana ilinde yer alan bir eğitim hastanesinin ÇYBÜ’ne gelen hasta sayıları hareketli ortalama, üstel düzeltme ve uygun ARIMA modeli ile tahmin edilmiştir. Bu amaçla, hastanenin ÇYBÜ’nde tedavi görmüş dört yıllık hasta sayıları kullanılmıştır. Mevcut veriler düzenlemiş ve Tablo 1'de verilmiştir. 
Tablo 1. 2015-2018 Yılları Arası Aylık Hasta Sayısı

\begin{tabular}{l|llll}
\hline \multirow{2}{*}{ Ay } & \multicolumn{4}{|c}{ Yıllar } \\
\cline { 2 - 5 } & $\mathbf{2 0 1 5}$ & $\mathbf{2 0 1 6}$ & $\mathbf{2 0 1 7}$ & $\mathbf{2 0 1 8}$ \\
\hline Ocak & 82 & 89 & 82 & 91 \\
Şubat & 73 & 69 & 45 & 70 \\
Mart & 87 & 79 & 74 & 75 \\
Nisan & 91 & 74 & 64 & 88 \\
Mayıs & 72 & 90 & 63 & 89 \\
Haziran & 95 & 83 & 68 & 65 \\
Temmuz & 100 & 77 & 71 & 80 \\
Ağustos & 97 & 92 & 54 & 75 \\
Eylül & 77 & 56 & 64 & 77 \\
Ekim & 93 & 70 & 77 & 65 \\
Kasım & 61 & 64 & 69 & 92 \\
Aralık & 84 & 62 & 79 & 95 \\
\hline
\end{tabular}

\subsection{Metod}

Zaman serisi, ardışık ve eşit aralıklı zamanlarda bir bağımsız değişkenin aldığı değerleri gösteren küme olarak tanımlanabilir. Zaman serileri, tahmini yapılmak istenilen değişkene göre "saat, gün, hafta, ay, üç ay ve yıl" gibi farklı zaman birimleri ile sıralanabilir (Karasu, 2000:85). Zamana bağlı bir değişkenin gelecekte alacağı değer farklı zaman serileri yöntemleri ile belirlenebilmektedir. Çalışma kapsamında zaman serisi yöntemleriden, üstel düzeltme, hareketli ortalama ve Box-Jenkins yöntemi kullanılmıştır. Kullanılacak yöntemi belirlerken ilk aşamada zaman serisi analizi gerçekleştirilerek zaman serisinde mevcut olan etki ve kalıplar ortaya konmalı, sonrasında seriyi en iyi temsil edecek model belirlenmelidir.

Zaman serisi, sabit bir seviye veya ortalama etrafında dalgalandığında, yatay bir kalıp vardır. Bu tür serinin genel olarak durağan olduğu kabul edilir. Eğer veriler, zaman ilerledikçe artan veya azalan bir görünüm sergiliyorlarsa eğilim etkisinin söz konusu olduğu söylenebilir. Mevcut artış ve azalışlar zamana göre doğrusal olabildiği gibi bazen de doğrusal olmayan bir yapı ortaya koyabilir. Bir zaman serisinde 3 aylık, aylık veya haftalık gibi bir yıl içerisinde özel bir zaman diliminde periyodik olarak artış veya azalışlar meydana geliyorsa, zaman serisinin mevsimsel kalıp sergilediği anlaşılır. Konjonktür dalgalanmalar ise uzun dönemli ve eğilim eğrisi etrafinda artış ve azalışlar şeklinde oluşan dalgalanmalardır (Özek, 2000:124). Zaman serilerinin analizi ve kalıpların belirlenmesi için zaman serisi grafiğinden faydalanılabiliceği gibi farklı zaman gecikmelerindeki otokorelasyon katsayılarını gösteren grafik (otokorelasyon fonksiyonu) incelenebilir. Otokorelasyon fonksiyonu, bir zaman serisinin çeşitli gecikmeleri için otokorelasyonlarının bir grafiğidir. Aşağıdaki bölümlerde, çalışma kapsamında kullanılan üstel düzeltme, hareketli ortalama ve Box-Jenkins yöntemleri kısaca anlatılmıştır.

\subsubsection{Hareketli Ortalamalar Yöntemi}

Hareketli ortalamalar yöntemi, geçmiş dönemlere ait $n$ adet dönem verisinin ortalamasını, bir sonraki dönemin tahminini elde etmek için kullanır. Hareketli ortalamaya dâhil edilecek gözlem sayısı öngörüyü yapacak kişi tarafından belirlenmekte ve sabit kalmaktadır. Hareketli ortalamalar yönteminin amacı, tesadüfi etkenlerin neden olduğu değişimleri bir ölçüde elimine etmektir. Böylece, yönetici dikkatini kaynağı bilinen değişimler üzerine yoğunlaştırarak daha doğru kararlar alabilir (Kobu, 2014: 122, Heizer\&Render, 2017: 110). Matematiksel olarak basit hareketli ortalama aşağıdaki gibi ifade edilebilir:

$$
F_{t+1}=\frac{Y_{t}+Y_{t-1}+\cdots+Y_{t-n+1}}{n}
$$

Burada:

$F_{t+1}: \mathrm{t}+1$ dönemindeki tahmin değeri

$Y_{t}:$ t dönemindeki gerçek değer

n: hareketli ortalamaya dahil edilen gözlem sayısıdır.

Saptanabilir bir eğilim sözkonusu ise, en yeni değerlerin önemini belirtmek ve model içine yansıtabilmek amacıyla ağırlıklar kullanılabilir (Heizer\&Render, 2017: 111). Bu durumda yöntem ağırlıklı hareketli ortalama olarak adlandırılır. 


\subsection{2. Üstel Düzeltme Yöntemi}

Üstel düzeltme yöntemi de hareketli ortalama yönteminde olduğu gibi tesadüfi etkenlerin neden olduğu değişmeleri elimine etmeyi amaçlamaktadır. Üstel düzeltme yönteminde basit aritmetik ortalama yerine, son gerçek ve tahmini değerlere uygun ağırlıklar verilerek bir çeşit ağırlıklı ortalama alınır. Yöntemi uygulayabilmek için öncelikle sıfır ile bir arasında değişen bir $\alpha$ katsayısı belirlenir (Kobu, 2014: 124). Talep tahminini gerçekleştirmek için kullanılan birçok paket program, en uygun $\alpha$ katsayısını belirleyerek işlemi gerçekleştirebilmektedir. Üstel düzeltme yönteminin matematiksel ifadesi Eşitlik (2)'de verilmiştir.

$F_{t+1}=\alpha Y_{t}+(1-\alpha) F_{t}$

\subsubsection{Box-Jenkins Modeli}

Box-Jenkins yöntemleri, otoregresif birleştirilmiş hareketli ortalamalar (autoregressive integrated moving average, ARIMA) olarak adlandırılmıştır. Genel olarak ARIMA modeli ile talep tahmini aşamaları aşă̆ıdaki gibi verilebilir (Hanke\&Winchern, 2009:400).

- Uygun ARIMA modelini belirlemenin ilk adımı, serinin durağan olup olmadığını belirlemektir (yani zaman serisinin sabit bir seviye ya da ortalama etrafında değişip değişmediğinin) belirlenmesidir. Eğer zaman serisi grafiğinde, verilerin zaman içerisinde bir artış veya azalış eğilimi içerisinde olduğu ve otokorelasyon grafiğinden de otokorelasyon değerlerinin özellikle ilk birkaç zaman gecikmesinde (lag) anlamlı derecede büyük olduğu ve yavaş bir şekilde düşüş gösterdiği gözleniyorsa, zaman serisinin durağan olmadığı söylenir. Seri durağan değilse, verideki durağan olmayan yapının arındırılması amacıyla, serinin ihtiyacına göre bir kaç kere farkı alınarak durağanlık sağlanabilir. Fark alma işlemi, zaman serisi grafiğinde eğilimin gözlenmediği veya otokorelasyon değerlerinin oldukça hızlı bir şekilde düşüş gösterdiği durum sağlanıncaya kadar gerçekleştirilir. Durağan olmayan seriler için kullanılan model genel olarak ARIMA (p,d,q) modeli olarak adlandırılır. Burada; d, orijinal seri durağan olmadığı durumda seriyi durağan hale getirebilmek için kaç kere fark alındığını ifade eder. Eğer orijinal seri durağan ise o zaman model, ARMA modeline indirgenir veya $\operatorname{ARIMA}(\mathrm{p}, 0, \mathrm{q})$ olarak gösterilebilir.

- Durağan bir seri elde edildikten sonra ikinci adım, kullanılacak modelin formunun belirlenmesidir. Diğer bir ifade ile serinin, AR( p) veya MA(q) modellerinden hangisine uyduğunun ortaya konulmasıdır. Bu amaçla, zaman serisine ait otokorelasyon ve kısmi otokorelasyon grafikleri, çeşitli ARIMA modelleri için geliştirilmiş teorik otokorelasyon ve kısmi otokorelasyon grafikleri ile kıyaslanır. Bu sayede, tahminde kullanacak ilk model sezgisel olarak belirlenmiş olur.

- Elde edilen ve tahminin yapılmasında kullanılan ilk modele ait parametrelerin istatistiksel olarak anlamlı olup olmadıkları test edilir. İstatistiksel olarak anlamlı olan parametreler modelde kalırken, anlamlı bulunmayan parametreler modelden uzaklaştırılır ve model revize edilerek yeniden test edilir.

- Son olarak, model uygunluğunun kontrolü Ljung-Box Q istatistiklerine dayanan ki-kare testi ile sağlanır. Q istatistiğiyle ilişkili p değeri küçükse (örneğin, $\mathrm{p}$ değeri <.05) ise model yetersiz kabul edilir. Modelin yetersiz olması durumunda, revize edilerek yeni bir model test edilir.

Box-Jenkins metodolojisine göre tahmin edilen herhangi bir modelin hata terimleri rassal bir dağılıma sahipse o model uygun model olarak kabul edilmektedir. Uygun ARIMA modeli belirlenirken temel amaç en az sayıda parametre içeren en uygun formun belirlenmesidir Genel olarak bir ARIMA( p,d,q) modelinin matematiksel gösterimi aşağıdaki gibidir (Hanke ve Wichern, 2014: 407):

Genel olarak p. ve q. dereceden bir ARMA (p, q) modeli (Hanke ve Wichern, 2014: 407):

$Y_{t}=\emptyset_{0}+\emptyset_{1} Y_{t-1}+\cdots+\emptyset_{p} Y_{t-p}+\varepsilon_{t}-\omega_{1} \varepsilon_{t-1}-\omega_{2} \varepsilon_{t-2}-\cdots-\omega_{q} \varepsilon_{t-q}$

Burada:

$Y_{t}, Y_{t-1}, \ldots Y_{t-p}: t, t-1, t-p$ zamanlarına ait gözlem değerleri

$\emptyset_{0}, \emptyset_{1}, \ldots \emptyset_{p}:$ : tahmin edilen parametre değerleri

$\varepsilon_{t}: \mathrm{t}$ zamanına ait hata terimi

$\omega_{1}, \omega_{2}, \ldots, \omega_{\mathrm{t}-\mathrm{p}}:$ modelin katsayıları olarak ifade edilmektedir.

Serinin durağan olmaması durumunda, ilk olarak serinin durağan hale gelmesi için gerektiği kadar fark alma işlemi yapılır. Bu durumda, ARIMA modelleri ARIMA (p,d,q) ile gösterilir. Bu ifadede "d", serinin durağan hale gelmesi için alınmasu gereken fark sayısını gösterir. Eğer d, sıfıra eşitse ARIMA (p, 0, q) modeli, ARMA (p, q) modeli aynıdır (Hanke ve Wichern, 2014: 408).

\section{Araștırma Sonuçları ve Tartışma}

\subsection{ARIMA Modeli ile Tahmin}

Bir önceki bölümde açıklandığı gibi, uygun ARIMA modelinin belirlenmesi için öncelikle zaman serisi analizleri yapılmalıdır. Bu amaçla zaman serisi grafiği ve zaman serisine ait oto korelasyon grafikleri oluşturulmuştur. İlgili grafikler Şekil 1, Şekil 2 ve Şekil 3'de verilmiştir. 


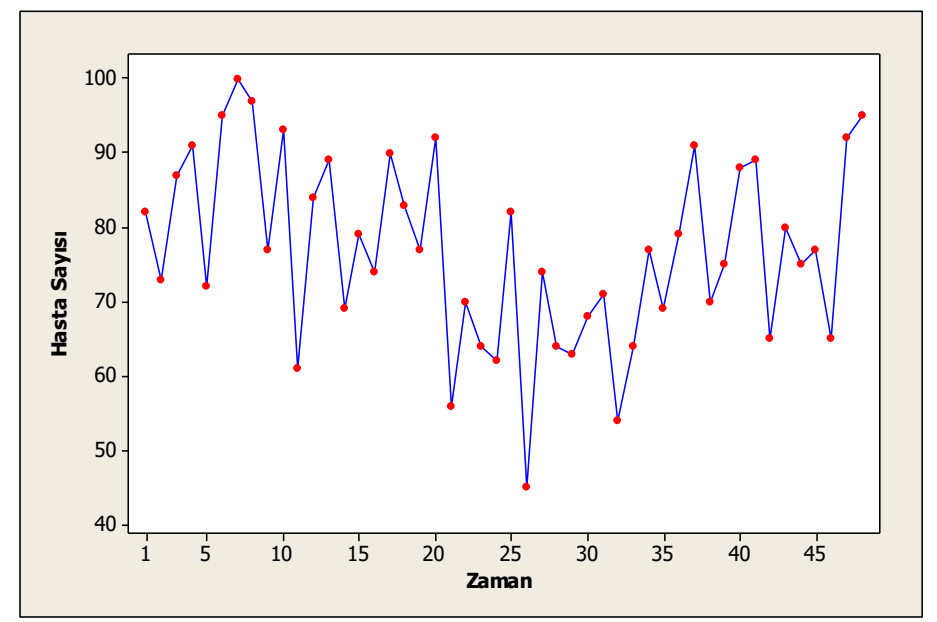

Şekil 1. Hasta saylsı zaman serisi grafiği

Zaman serisi grafiği incelendiğinde, serinin eğilim veya mevsimsellik unsurları taşıdığına dair bir görsel ortaya koymadığı görülmektedir. Ancak daha net değerlendirme yapmak amacıyla zaman serisine ait otokorelasyon grafiğine bakılmalıdır. Otokorelasyon grafiği, \%5 anlamlılık sınırı gösterilerek Şekil 2'de verilmiştir.

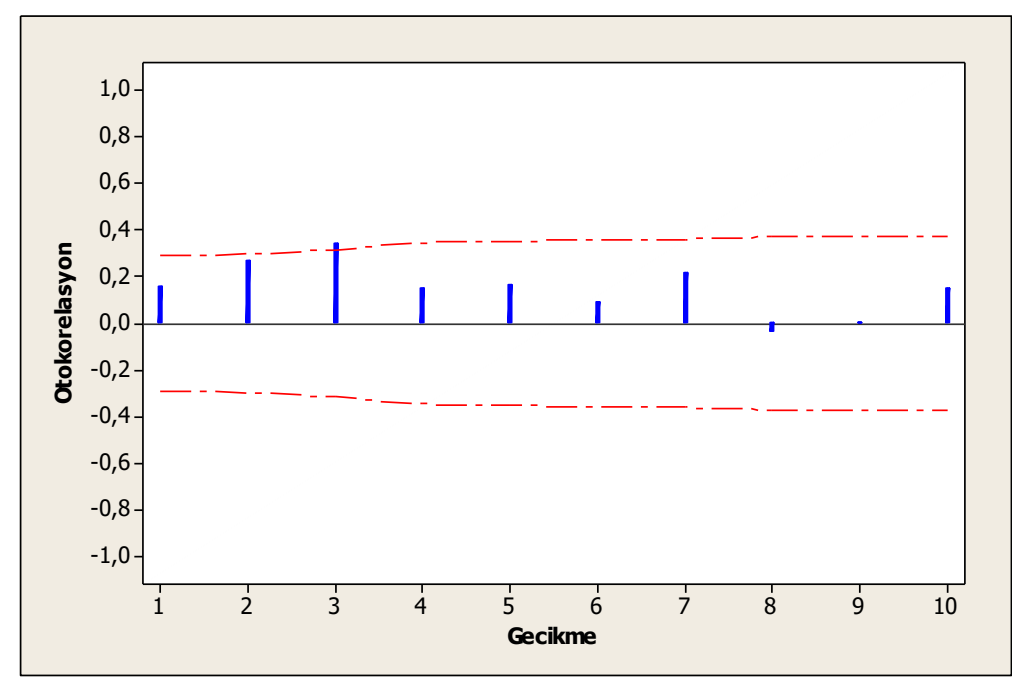

Şekil 2. Hasta saylsl verilerine ait otokorelasyon grafiği

Eğer veriler eğilim unsuru içeriyorsa ve durağan değilse, otokorelasyon değerlerinin özellikle ilk birkaç zaman gecikmesinde (lag) anlamlı derecede büyük olduğu ve yavaş bir şekilde düşüş gösterdiği gözlenmelidir. Ancak, bu durum Şekil 2'de gözlenmemektedir. Dolayısıyla serinin durağan olduğu söylenebilmektedir. Bu durumda, zaman serinin durağanlaştırılması için fark alınmasına ihtiyaç duyulmayacaktır. Ayrıca otokorelasyon grafiği, mevsimselliğe dair de herhangi bir bulgu ortaya koyamamaktadır. Uygun ARIMA (p, 0 , q) formunun belirlenebilmesi amacıyla, seriye ait kısmi otokorelasyon grafiği de incelenmelidir (Şekil 3).

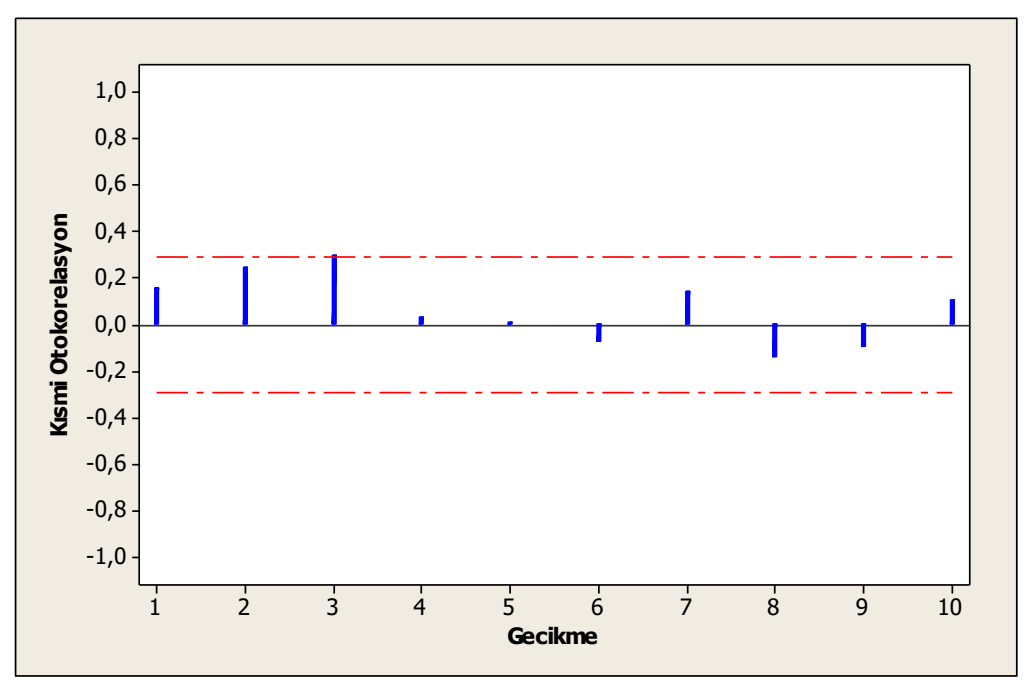

Şekil 3. Hasta saylsı verilerine ait klsmi otokorelasyon grafiği 
Kısmi otokorelasyon ile otokorelasyon grafikleri birlikte değerlendirildiklerinde ve teorik otokorelasyon grafikleri incelendiğinde (Hanke\&Wichern, 2009:357-359), ARIMA(1,0,1) modelinin uygun olabileceği düşünülmüştür. Modele ait istatistikler Tablo 2'de verilmiştir.

Tablo 2. ARIMA $(1,0,1)$ modeline ait istatistikler

\begin{tabular}{|l|l|l|l|l|}
\hline \multicolumn{5}{|l|}{ Parametre Tahmin Verileri } \\
\hline Değişken & Katsay1 & Std.Hata & T-ist. & P \\
\hline AR(1) & 0,8938 & 0,1417 & 6,31 & 0,000 \\
\hline MA(1) & 0,7115 & 0,2214 & 3,21 & 0,002 \\
\hline Sabit & 8,2992 & 0,5113 & 16,23 & 0,000 \\
\hline Ortalama & 78,113 & 4,812 & & \\
\hline SS & 6476,86 \\
\hline MS(OHK) & 143,93 (DF=45) \\
\hline Ljung-Box Ki-Kare İstatistiği \\
\hline Gecikme & 12 & 24 & 36 & 48 \\
\hline Ki-Kare & 9,6 & 18 & 33,1 & $*$ \\
\hline DF & 9 & 21 & 33 & $*$ \\
\hline P-değeri & 0,381 & 0,652 & 0,462 & $*$ \\
\hline
\end{tabular}

Parametrelerin anlamlılı̆̆ analiz edildiğinde, önerilen modeldeki parametrelerin istatistiksel olarak anlamlı olduğu $(\mathrm{p}<0,05)$ görülmektedir. Model parametrelerinin anlamlılı̆̆ı "p" değeri göz önüne alınarak aşağıdaki hipotez ile test edilmektedir:

$$
\begin{gathered}
H_{0}: \rho_{1}=0 \text { (model parametreleri anlamslzdır) } \\
H_{1}: \rho_{1} \neq 0
\end{gathered}
$$

AR(1), MA (1) ve sabit terim için p değerleri, 0,05 değerinden küçüktür. Bu bakımdan, $H_{0}$ hipotezi reddedilir. Bu durumda, model parametrelerinin istatistiksel olarak anlamlı olduğu, dolayısıyla modelde kalmaları gerektiği anlaşılır.

Aynı zamanda, Tablo 2'deki “Ljung-Box” test verileri incelendiğinde, farklı eksiltme seviyelerindeki $(12,24,36)$ p değerlerinin de 0,05 'den büyük olduğu için modelin uygun olduğunu görmekteyiz. Modele ait hata değerlerinin otokorelasyon (Şekil 4) ve kısmi otokorelasyon grafikleri (Şekil 5) de incelendiğinde hata değerlerinin rassal olduğu gözlenmiştir.

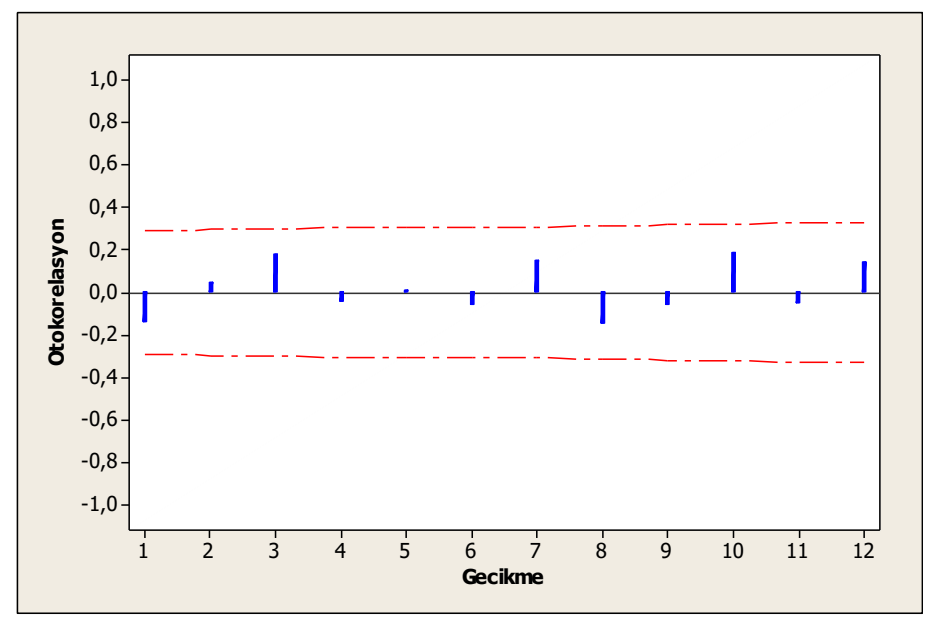

Şekil 4. ARIMA $(1,0,1)$ modelinin hata de ğerlerine ait otokorelasyon grafiği 


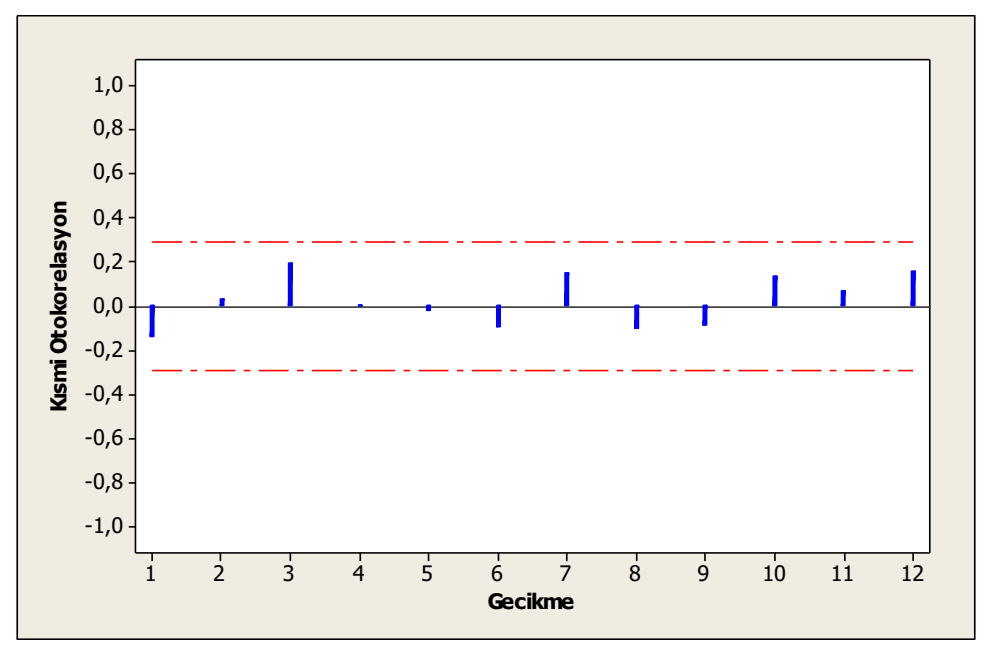

Şekil 5. ARIMA $(1,0,1)$ modelinin hata değerlerine ait kismi otokorelasyon grafiği

Hata değerlerine ait otokorelasyon ve kısmi otokorelasyon değerleri \%5 anlamlılık düzeyleri içerisinde kalmış ve dolayısıyla tüm zaman periyodları için hata değerlerinin limitler arasında kaldığı görülmüştür.

Çocuk yoğun bakım ünitesine gelecek aylarda başvuracak hasta talebi için uygun olan ARIMA(1,0,1) modeli Eşitlik (4)'den faydalanılarak, aşağıdaki gibi ifade edilebilmektedir:

$Y_{49}=8,2992+0,89438+0,5113-0,7115 \varepsilon_{48}$

Paket programın çıktılarına göre 2019 yılının ilk iki ayı için tahmin sonuçları aşağıdaki Tablo 3' de verilmiştir.

Tablo 3. ARIMA(1,0,1) modelinden elde edilen tahmin sonuçları

\begin{tabular}{l|l|l|l}
\hline \multirow{2}{*}{ Periyod } & \multirow{2}{*}{ Tahmin } & \%95 Güvenlik Aralı̆̆ & \\
\cline { 3 - 4 } & & Alt limit & Üst limit \\
\hline 49 & 81,523 & 58,004 & 105,042 \\
\hline 50 & 81,161 & 57,254 & 105,067 \\
\hline
\end{tabular}

Kurulan model üzerinden 2019 yılının ocak ayı için tahmin yaptığımızda, program ile aynı sonucu elde edildiği görülmektedir.

$Y_{49}=8,2992+0,8938 * 95+0,5113-0,7115 * 16,4197$

$Y_{49}=81,5276$

Ortalama Mutlak Yüzde Hata (OMYH) değeri modelin doğruluğuna ait bilgi sunan önemli hata ölçütlerinden biridir. Lewis (1982) çalışmasında, OMYH değeri \%10'dan düşük olan modelleri "ç̧ok iyi”, \%10 ile \%20 arasında olan modelleri "iyi”, \%20 ile \%50 arasında olan modelleri "kabul edilebilir" ve \%50'nin üzerinde olan modelleri ise "yanlış ve hatalı" olarak nitelendirilmiştir (Karahan, 2015). Önerilen ARIMA modeli için hata değerleri dikkate alınarak hesaplanan OMYH, \%13,3 olarak hesaplanmış ve bu nedenle iyi bir tahmin edici olarak kabul edilebileceği görülmüştür.

\subsection{Hareketli Ortalama ve Üstel Düzeltme Yöntemleri ile Tahmin}

Bu bölümde, çocuk yoğun bakımda hizmet görecek hasta sayısı tahmini zaman serisi yöntemlerinden olan üstel düzeltme ve hareketli ortalama yöntemleri kullanılarak elde edilmiştir.

Hareketli ortalama yöntemi uygulanmadan önce, hareketli ortalamadaki dönem sayısının belirlenmesi gerekmektedir. Dönem sayısını belirlenmesinde kesin bir yöntem yoktur. Ancak, makul sayıdaki dönemleri içeren hareketli ortalama sonuçları hata ölçütlerinden biri dikkate alınarak kıyaslanabilir. Mevcut çalışmada, 3 aylık ve 5 aylık hareketli ortalama yöntemleri uygulanmış ve sonuçlar hata ölçütlerine göre kıyaslanmıştır. 


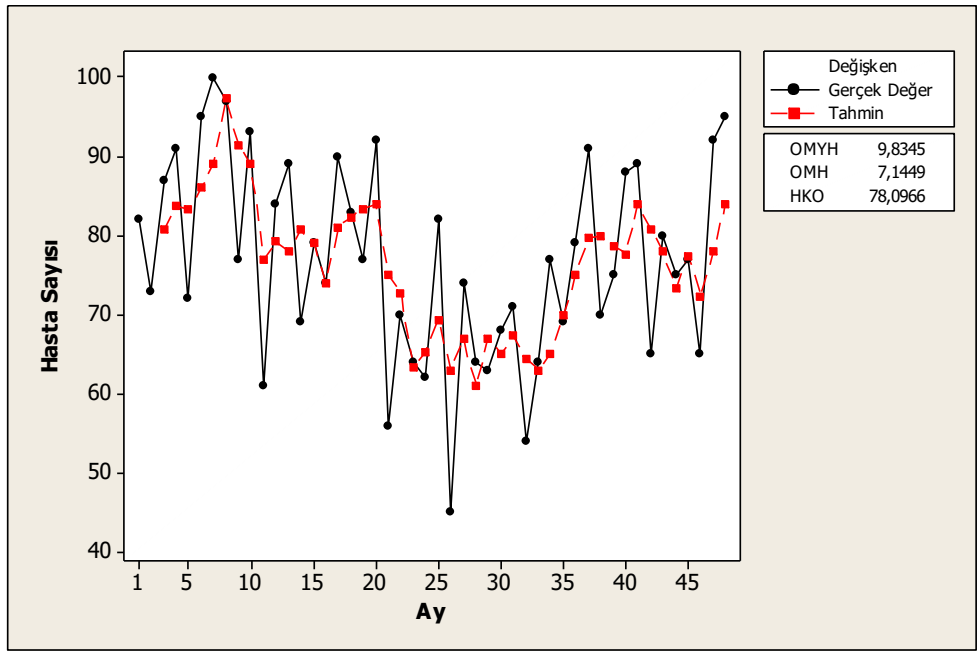

Şekil 6. Serinin 3 aylık hareketli ortalama ile tahmini

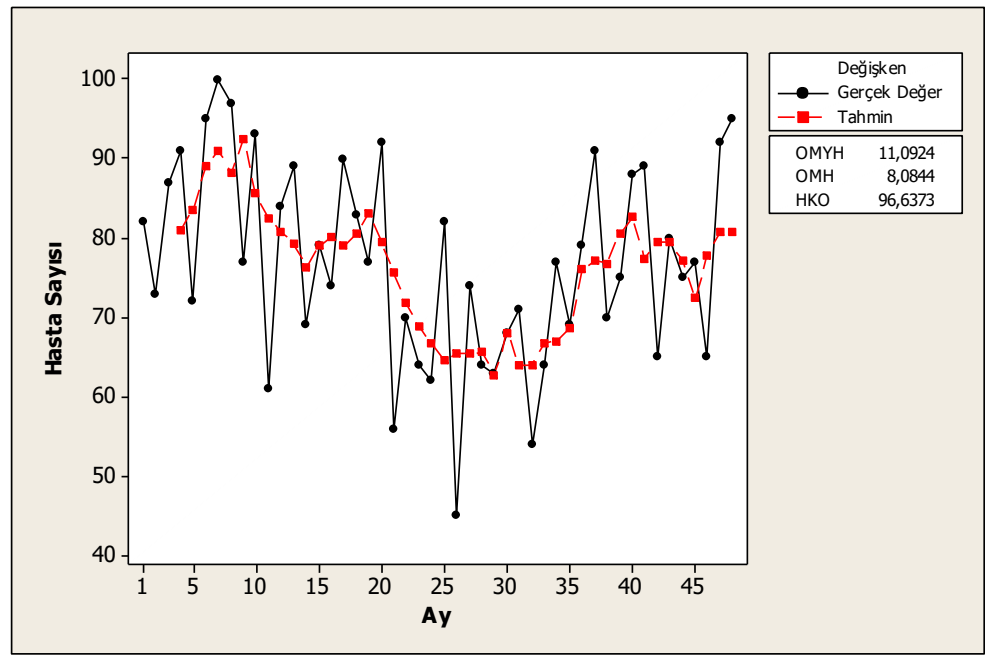

Şekil 7. Serinin 5 aylık hareketli ortalama ile tahmini

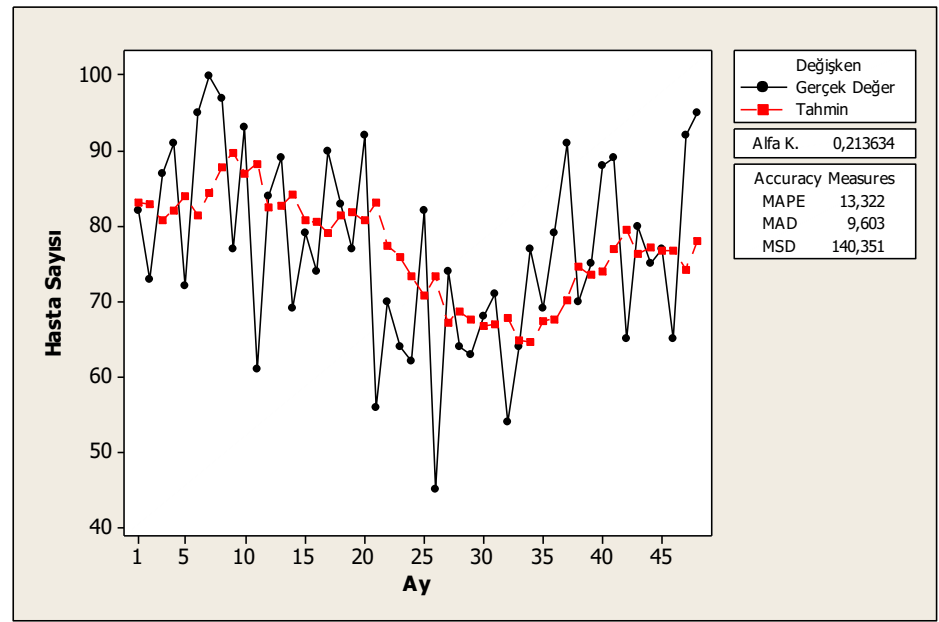

Şekil 8. Serinin üstel düzeltme yöntemi ile tahmini

Çocuk yoğun bakım hasta serisinin tahmini için üç aylık ve beş aylık olmak üzere iki farklı hareketli ortalama tahmini ve alfa katsayısının program tarafından en uygun olarak belirlendiği üstel düzeltme yöntemi uygulanmıştır. Yöntemlere ait grafikler gerçek değerleri ve tahmini değerleri gösterecek şekilde sırasıyla Şekil 6, Şekil 7 ve Şekil 8'de verilmiştir. Mevcut yöntemlerden elde edilen tahminlerin performans ölçütleri Tablo 4' de özetlenmiştir. 
Tablo 4. Hareketli ortalama ve üstel düzeltme yöntemleri performans ölçütleri

\begin{tabular}{c|c|c|c}
\hline Yöntem & OMYH & OMH & HKO \\
\hline Hareketli Ortalama (n=3) & 9,83 & 7,14 & 78,09 \\
\hline Hareketli Ortalama (n=5) & 11,09 & 8,08 & 96,64 \\
\hline Üstel Düzeltme & 13,32 & 9,60 & 140,35 \\
\hline
\end{tabular}

Tablo 4 incelendiğinde, $n=3$ alınarak elde edilen tahmin değerlerine ait her üç hata ölçütünün de diğerlerinden daha iyi olduğu görülmektedir. Ayrıca üç aylık hareketli ortalama için elde edilen OMYH değeri, önerilen ARIMA modelinden de daha iyi sonuç vermiştir.

\section{Sonuç}

Zaman serileri ile ifade edilen geçmiş verilerin istatistiksel teknikler kullanılarak analizi ve uygun tahmin yönteminin belirlenmesi üretim sektöründe olduğu kadar hizmet sektörü açısından da oldukça önemlidir. Özellikle söz konusu olan hastaneler ise kapasite ile ilgili kararlar alınmadan ve planlama aşamasına geçilmeden önce muhakkak uygun bir tahmin yöntemi elde edilmiş talep tahmininin bilinmesi gerekmektedir. Aksi takdirde, kaynağın yetersiz planlanması can kaybı ile sonuçlanabilmektedir.

Mevcut çalışmada, büyük ölçekli bir eğitim hastanesinin ÇYBÜ’sinde 2015-2018 yılları arasında tedavi gören hasta sayısı verileri dikkate alınarak, en uygun talep tahmini yönteminin belirlenmesi amaçlanmıştır. Zaman serisi incelendiğinde, serinin bir ortalama etrafında dağıldığı ve eğilim ya da mevsimsellik içermediği görülmüştür (Şekil 1). Üç farklı zaman serisi yöntemi seriye uygulanmış ve OMH, HKO, OMYH gibi performans ölçütleri ortaya konmuştur. OMYH değeri \%10'dan düşük olan modellerin "çok iyi”, \%10 ile $\% 20$ arasında olan modellerin ise iyi modeller olarak sınıflandırılabileceği bilinmektedir (Karahan, 2015). Bu durumda, üstel düzeltme ve hareketli ortalama yöntemi mevcut seri için çok iyi, ARIMA modeli ise iyi bir tahmin edicidir. Tahmin hatası ölçütleri yöntemler bazında kıyaslandığında ise, üç aylık hareketli ortalamanın diğer yöntemlere göre daha iyi olduğu görülmüştür.

Bu bulgular ışığında, daha karmaşık modelin herzaman için daha iyi sonuç vereceği anlamına gelmediği görülebilmektedir. Aynı zamanda, ÇYBÜ’de yatan hasta sayısının zaman serileri ile modellenebileceği görülmektedir. Elde edilen tahmin sonuçlarının, yöneticelere kaynak planlama da kullanabilecekleri önemli bir girdi sağlayacağı düşünülmektedir.

\section{Kaynakça}

Çocuk Acil Tıp ve Yoğun Bakım Derneği, 2006 yılı Pediatrik Yoğun Bakım Raporu, Erişim adresi: http://www.cayd.org.tr/gorseller/files/raporlar/\%C3\%87ocuk\%20Yo\%C4\%9Fun\%20Bak\%C4\%B1m\%20Hizmetleri\%202006.pdf

Güner A., (2014). Bayesci yaklaşımda eşlenik aileleri önseli ile jeffreys önselinin karşılaştırılması, Yüksek Lisans Tezi, Eskişehir Osmangazi Üniversitesi, Fen Bilimleri Enstitüsü, İstatistik Anabilim Dalı.

Hanke, J.E. \& Wichern, D. (2014). Business Forecasting. England: Pearson Education.

Heizer, R. \& Render, B. (2017). Üretim Yönetimi: Sürdürülebilirlik ve Tedarik Zinciri Yönetmi. Ankara: Palme Yayıncılık.

Karahan, M., (2015). Yapay Sinir Ağları Metodu ile İhracat Miktarlarının Tahmini: ARIMA ve YSA Metodunun Karşılaştırmalı Analizi, Ege Akademik Bakış, 15(2), 165-172.

Kobu, B.(2014). Üretim Yönetimi. Beta, 17. basım.

Konca, Ç.,Tekin, M., Karakoç, F., Turgut, M. (2015). Çocuk Yoğun Bakım Ünitesinde Yatan 770 Hastanın Değerlendirilmesi: Tek Merkez Deneyimi, Türkiye Çocuk Hastalıkları Dergisi, 2, 90-95.

Kress, J. G. \& Snyder J., (1994). Forecasting and Analysis Techniques, eBook, May.

Özdemir, A., Özdemir, A., (2006). Talep Tahminlemesinde Kullanılan Yöntemlerin Karşılaştırılması: Seramik Ürün Grubu Firma Uygulaması, Ege Academic Review, 6(2), 105-114.

Özüdoğru, A. G., Görener, A., (2015), Sağlık Sektöründe Talep Tahmini Üzerine Bir Uygulama, İstanbul Ticaret Üniversitesi Sosyal Bilimleri Dergisi 14(27), 37-53.

Sarıyer, G., (2018).Acil Servislerde Talebin Zaman Serileri Modelleri ile Tahmin Edilmesi, Kırlkkale Üniversitesi, Mühendislik Fak. Uluslararası Mühendislik Araştırma ve Geliştirme Dergisi, 10( 1). 